\title{
Practical Applications of Phthalocyanines - from Dyes and Pigments to Materials for Optical, Electronic and Photo-electronic Devices
}

\author{
Dieter Wöhrle, ${ }^{a}$ Günter Schnurpfeil, ${ }^{\text {a }}$ Sergey G. Makarov, ${ }^{\text {b }}$ Alexander Kazarin, ${ }^{\text {b }}$ and \\ Olga N. Suvorovab
}

${ }^{a}$ Universität Bremen, Institut für Organische und Makromolekulare Chemie, 28334 Bremen, Germany

${ }^{\mathrm{b}}$ Russian Academy of Sciences, Institute of Organometallic Chemistry, 603950 Nizhnii Novgorod, Russia

${ }^{\circledR}$ Corresponding author E-mail: woehrle@uni-bremen.de

\begin{abstract}
Phthalocyanines $(P c)$ produced for 75 years as blue and green pigments are the most important organic colorants. Color fastness, homogeneity, intensity, stability combined with a simple synthetic access is the prerequisite of this mostly planar aromatic $\pi$-system for application as colorants. In the recent years the Pc found also applications in CD/ $R s$, as blue and green colors in LCDs, as photoconductor in laser printers and as p-conductor and absorber in organic solar cells. The system exhibits a great structural variability (different substituents and metals/metalloids in the ligand) in order to tune different properties. For various applications is also important a relatively simple synthesis. These are the presuppositions for new applications of Pcs in future also in other fields.
\end{abstract}

Keywords: Phthalocyanines, colorants, CD/R, LCD, laser printers, solar cells.

\section{Практическое применение фталоцианинов - от красителей и пигментов Ао материалов Аля оптических, электронных и фотоэлектронных устройств}

\author{
А. Вёрле, ${ }^{a} @ \Gamma$ Шнурпфайль, ${ }^{a}$ С. Г. Макаров, ${ }^{b}$ А. Казарин, ${ }^{\mathrm{b}}$ О. Н. Суворова ${ }^{\mathrm{b}}$ \\ ${ }^{\text {a } У н и в е р с и т е т ~ Б р е м е н а, ~ И н с т и т у т ~ о р г а н и ч е с к о и ̆ ~ и ~ м а к р о м о л е к у л я р н о и ̆ ~ х и м и и, ~} 28334$ Бремен, Германия \\ ${ }^{\mathrm{b}}$ Институт металлоорганической химии РАН, 603950 Нижний Новгород, Россия \\ ${ }^{\circledR}$ E-mail: woehrle@uni-bremen.de
}

\begin{abstract}
Фталоцианины (Рc) производятся уже 75 лет и как синие и зеленые пигменты относятся к наиболее важным органическим красителям. Устойчивая, интенсивная и однородная окраска в сочетании с синтетической доступностью этих плоских ароматических л-систем определяет их широкое использование в качестве эффективных красителей. В последние годы фталоцианины нашли применение также в записываюших yстройствах (CD/R), в жидкокристаллических дисплеях (синие и зеленье цвета), как фотопроводники в лазерных принтерах, а также как поглотители излучения и р-проводники в органических в солнечных ячейках. Варьируя заместители в макроцикле и природу металла-комплексообразователя в молекуле фталоцианина, удобно направленно изменять свойства системь. Важную роль для широкого использования фталоцианинов имеет также относительная простота их получения. Все это является предпосылками для расширения применения фталочианинов и в других областях.
\end{abstract}

Ключевые слова: Фталоцианины, красители, CD/R, LCD, лазерные принтеры, солнечные батареи. 


\section{Introduction}

The phthalocyanine $\mathbf{1}$ is a macrocyclic compound exactly named $29 H, 31 H$-tetrabenzo[b,g,l,q]-5,10,15,20tetraazaporphine (recent reviews see ${ }^{[1]}$ ). The dianionic ligand with $42 \pi$ electrons exhibits a pronounced aromatic character according to the Hückel rule $(4 n+2)$ with $n=10$. The combination of aromaticity in an extended $\pi$-system including four fused benzenoid aromatics is essential not only for intense color in the visible range of $\lambda \sim 650-750 \mathrm{~nm}$ but also especially in the solid state for an excellent thermal and chemical stability of mostly planar Pcs. The Pc can contain in the center of the ligand two protons or about 66 metals and semimetals as cations in different oxidation states.

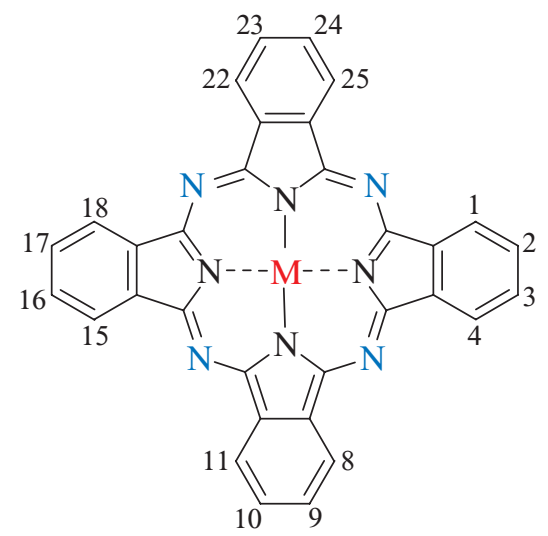

1

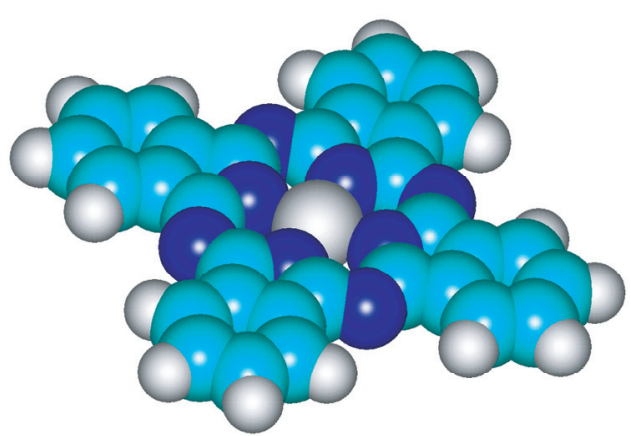

Phthalocyanines are widely used as blue and green colorants for decades. ${ }^{[2]}$ The worldwide production is about 80000 tonnes valued at over one billion U.S. dollars. Over 95\% are colorants. For applications as new tailor-made materials only small amounts are needed because as in thin films of material the required amount is less. The usage of colorants is about $40 \%$ for printing inks, about $30 \%$ varnish or paints, about $20 \%$ for coloring plastics and about $10 \%$ for other finishes. About $25 \%$ of synthetic organic pigments are Pcs and their derivatives. First, more shortly, it is interesting to explain in this article, why Pcs are important as colorants. In recent years Pcs found more and more special interest as new materials in optical, electronic and photo-electronic components ("devices"). Second, it is therefore necessary to explain why new applications for customized Pcs are opened.

\section{The First Issue for Applications: Simple to Perform Syntheses}

CuPc $1(\mathrm{M}=\mathrm{Cu})$ is the most important and cheap colorant (7-15 $\mathrm{C}$ per $\mathrm{kg}$ ). Industrially, the synthesis is carried out as the most inexpensive choice by cyclotetramerization of phthalic acid derivatives (such as phthalic acid anhydride 2), urea (as nitrogen source), a copper salt and a catalyst (Equation 1a). ${ }^{[2]}$ The reactions are conducted in the melt ("baking" process) at $150-300{ }^{\circ} \mathrm{C}$ or in a high boiling solvent such as 1,2,4-trichlorobenzene or kerosene at $\sim 200{ }^{\circ} \mathrm{C}$ resulting in $\sim 90 \% \mathrm{CuPc}$. The problem of this procedure is that a few percent of impurities remain in the product and it is difficult to remove them.

For new applications in optical, electronic and photoelectronic components compared to colorants lower amounts of Pcs but of "very high purity" are needed. In this case phthalonitrile $\mathbf{3}$ is employed as starting materials in the cyclotetramerization reaction (Equation $1 b) .{ }^{[1,2]}$ The reaction is carried out in the melt or in a solvent at 120 to $220^{\circ} \mathrm{C} \cdot{ }^{[3]}$ If, for example, $\mathrm{CuCl}_{2}$ is used in the reaction with $\mathbf{3}$, two electrons are needed to get the dianionic ligand which are available through the oxidation of $2 \mathrm{Cl}^{-}$to $\mathrm{Cl}_{2}$. A disadvantage may be here that $\mathrm{Cl}_{2}$ acts as electrophile in an aromatic substitution causing partially chlorinated products. Therefore it is better to employ metal acetates such as zinc(II) acetate. For purer products milder reaction conditions are necessary: reactions of phthalonitiles in high boiling alcoholes in the presence of $\mathrm{Li}$ alcoholates or in the presence of 1,8-diazabicyclo[5.4.0] undec-7-en (DBU) and then addition of metal acetates; 5 to 10 min batch reaction of $\mathbf{3}$ with metal acetates in a microwave oven (several publications exist, and only few references from the authors work are given ${ }^{[3,4]}$ ). Also metals $\mathrm{M}$ in an oxidation state higher than 2 can be incorporated into the dianionic ligand. Then $\mathrm{M}$ contains additional axial substituents. Examples are $\mathrm{M}$ in the oxidation state +3 such as $\mathrm{In}^{\mathrm{III}} \mathrm{ClPc}$ or $\mathrm{Ga}^{\mathrm{III}} \mathrm{ClPc}$ and in the oxidation state +4 such as $\mathrm{Si}^{\mathrm{IV}}(\mathrm{Cl})_{2} \mathrm{Pc}$ or $\mathrm{Ge}^{\mathrm{IV}}(\mathrm{Cl})_{2} \mathrm{Pc}^{[5]}$ The yields of Pcs are often $>70 \%$. It should be mentioned that the formation of $\mathrm{CuPc}$ from 3 with $\mathrm{Cu}$ is highly exothermic with an enthalpy of $\mathrm{AH}$ $=-830 \mathrm{~kJ} \cdot \mathrm{mol}^{-1}$ (driving force is formation of a new aromatic system!).

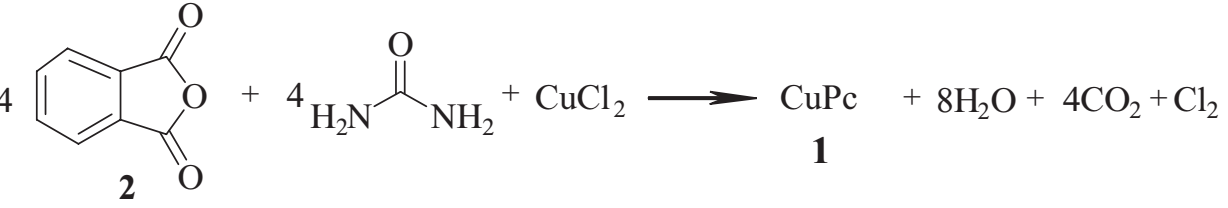<smiles>N#Cc1ccccc1C#N</smiles> 
A great challenge is the introduction of a great variety of substituents in peripheral positions of the benzene rings which remarkably influences the properties in the direction of tailor-made Pcs. Of industrial importance are electrophilic aromatic substitutions at Pcs obtained by the before mentioned phthalic acid anhydride process. [2] Up to 16 substituents can be introduced but statistically the positions 2,9(10), 16(17), 23(24) of the ligand exhibit highest reactivity. The halogenation of $\mathrm{CuPc}$ with chlorine and bromine in an eutectic mixture of $\mathrm{AlCl}_{3}$ and $\mathrm{NaCl}$ leads to a statistical mixture of products with a maximum of 11-12 bromo and 5-4 chlorine atoms which are used in green to yellow/green pigments. The statistical sulfonation, chloromethylation, sulfochlorination have significance for the introduction of reactive substituents which further can be converted by subsequent reactions to soluble dyes. For new advanced applications a selective substitution is essentail. In this case high purity phthalonitriles $\mathbf{4}$ or their ammonia adducts, the 1,3-diimino isoindolenines $\mathbf{5}$, bearing between one and four substituents are employed for the synthesis of 6 (Equation 2). Examples for substituents are: alkyl such as tert-buty ${ }^{[5 \mathrm{c} ; 6 a, b]}$ for good solubility in organic solvents; anionic $^{[6 c, \mathrm{~d}]}$ or cationic ${ }^{[4 \mathrm{~d} ; 5 \mathrm{~b}, \mathrm{~d}, \mathrm{e} ; 6 \mathrm{e}]}$ for water solubility; alkoxy or alkylthio with electron-donating character; ${ }^{[4 a-c ; 6 f, g]}$ fluoro, nitro, nitrile, with elektron-withdrawing character. ${ }^{[3 ; 4 a, e ; 6 h]}$ In the case of tetrasubstituted Pc's regio isomers are possible which are difficult to separate. ${ }^{[7]}$

Some interesting phthalocyanine analogues are shortly mentioned. Reaction of 2,3-dicyanonaphthalene with metal salts leads to naphthalocyanine $(\mathrm{Nc}) 7 .^{[8 a, b]}$ An interesting structural isomer of $\mathrm{Nc}$ is the long wavelength absorbing azulenocyanine (Az). ${ }^{[8 c]}$ 2,3-Dicyanoanthracene is the starting compound for anthracocyanine (Ac) ${ }^{[8 \mathrm{~d}]}$ The ionic radius of the element ions in the ligand has an influence on the size of the ligand. The majority of metals/metalloids leads to Pcs with four isoindole units (e.g. $\mathrm{Cu}^{2+}$ ionic radius $\left.72 \mathrm{pm}\right) . \mathrm{B}^{3+}$ has a very small ionic radius of $23 \mathrm{pm}$, and the reaction of $\mathrm{BCl}_{3}$ with 3 gives SubPc 8 containing only 3 isoindoles. ${ }^{[8]}$

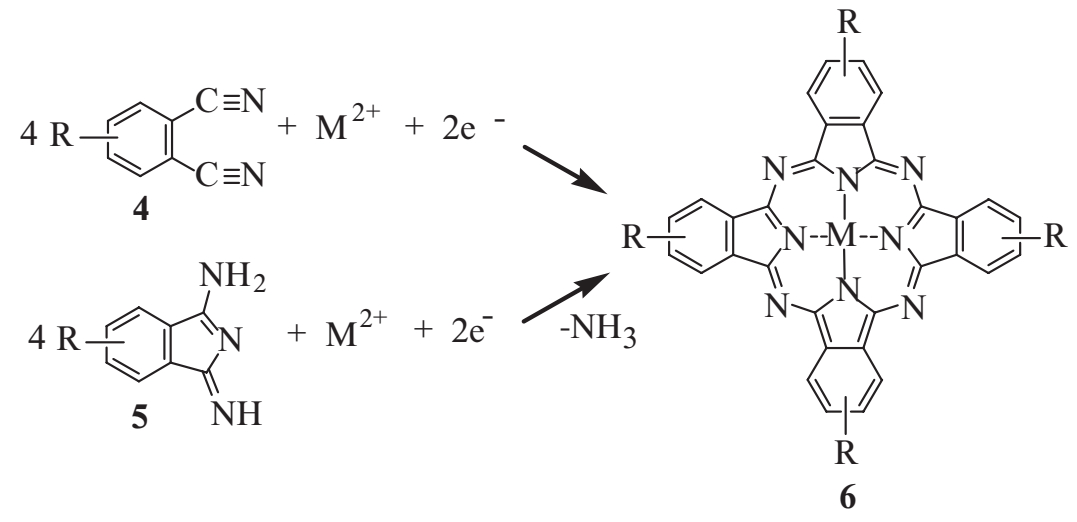

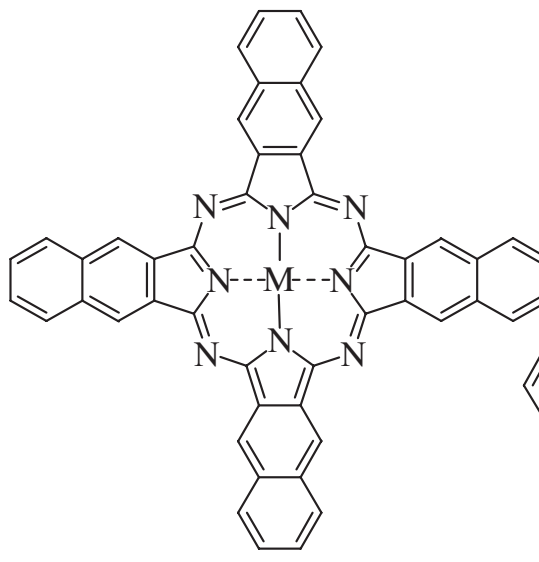

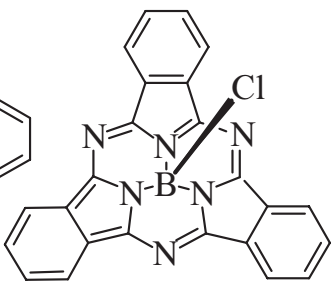

8

7

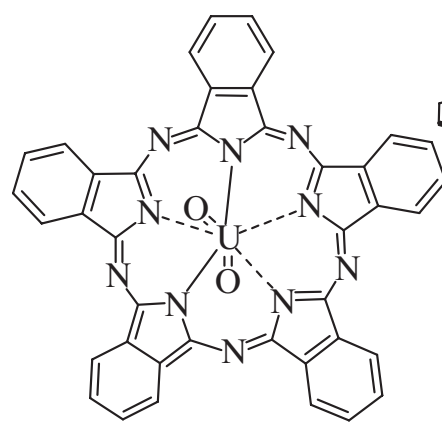

9

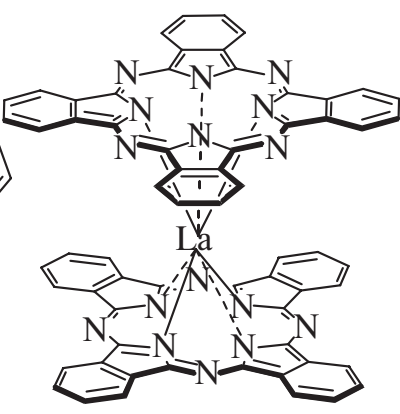

10
In contrast, the reaction of phthalonitrile with uranyl salts results in SuperPc 9 with 5 isoindoles $\left(\mathrm{U}^{4+}\right.$ ionic radius 97 $\mathrm{pm}) .^{[8 \mathrm{fg}]}$ Lanthanides form double-decker complexes, for example, bisphthalocyanato $\mathbf{1 0} .^{[8 \mathrm{~h}]}$

\section{The Second Issue for Applications: What Basic Properties Make Phthalocyanines so Valuable?}

An important issue for the coloration is the absorption of photons in the visible region up to the NIR which is characteristic for the most intense HOMO/LUMO transition ( $Q$ band) ${ }^{[1,2,8]}$ Monomolecular dissolved macrocycles exhibit an increase of the absorption wavelength by extending the $\pi$-system as follows: SubPc $\sim 560 \mathrm{~nm}<$ Pc $\sim 680 \mathrm{~nm}$ $<\mathrm{Nc} \sim 770 \mathrm{~nm}<\mathrm{Ac} \sim 830 \mathrm{~nm}<$ SuperPc $\sim 920 \mathrm{~nm} \cdot{ }^{[8]}$ But a disadvantage is that the stabilities are decreasing dramatically with extension of the $\pi$-system. ${ }^{[8 \mathrm{~d}, 9]}$ Pcs are superior for coloration because they show good stability against decomposition and are absorbing in dependence on the kind of substituents between $\lambda \sim 650$ and $\sim 750 \mathrm{~nm}$ with high

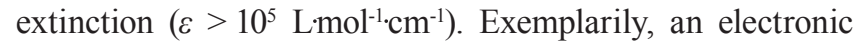
spectrum of the ZnPc 11 is shown in Figure 1. By enlargement of the $\pi$-system a red shift of the $Q$ band is observed: dinuclear $\mathrm{ZnPc} 12$ at $\lambda \sim 850 \mathrm{~nm}$ and trinuclear $\mathrm{ZnPc} 13$ at $\lambda \sim 950 \mathrm{~nm}^{\left[{ }^{[10]}\right.}$ Interesting are azulenocyanine (a structural isomer of $\mathrm{Nc}$ ) which exhibits absorptions at $\sim 1200 \mathrm{~nm} \cdot{ }^{[8]}$ For the use in CD/ Rs monomolecular distributed Pcs are important. 


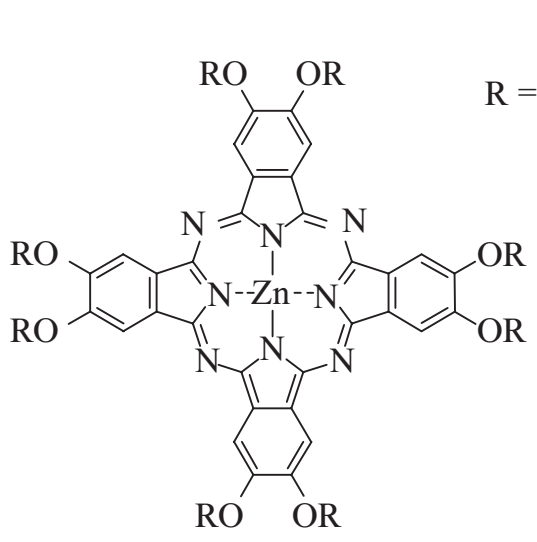

11

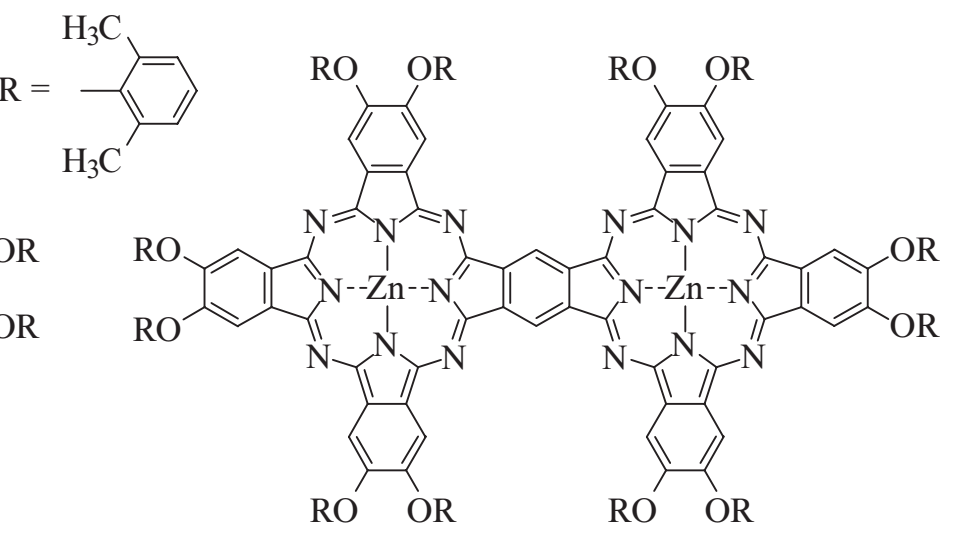

12

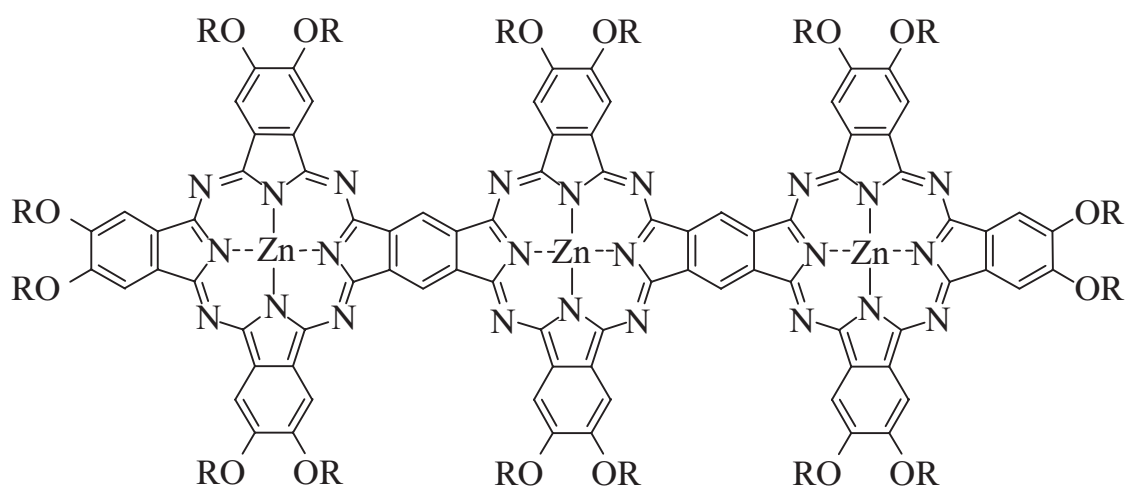

13

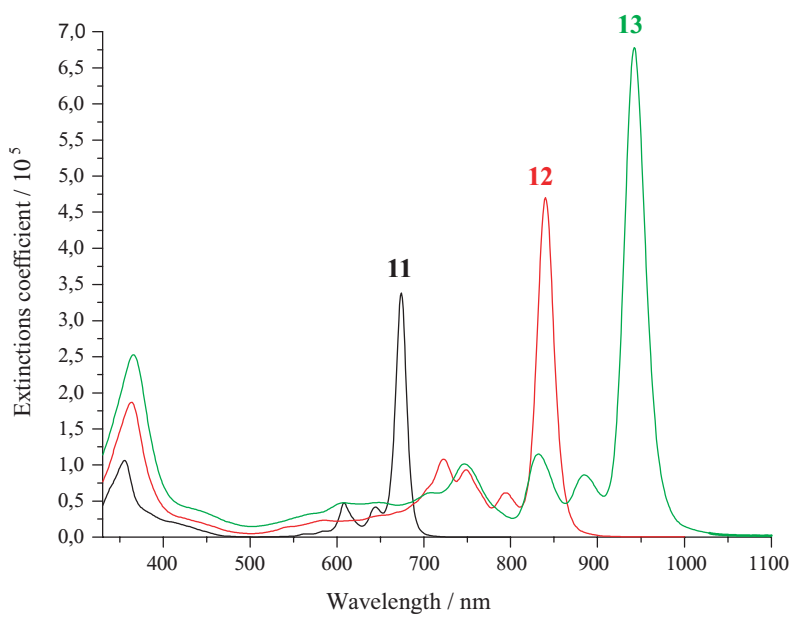

Figure 1. Absorption specta of $\mathbf{1 1}, \mathbf{1 2}$ and $\mathbf{1 3}$ in tetrahydrofurane. ${ }^{[10 a, b]}$
The spectra of aggregated Pcs in the solid state are more complex. The unsubstituted planar Pcs give various weak intermolecular $\pi$-electron and van der Waals interactions with the result of different ordered, crystalline arrays. For $\mathrm{CuPc} 1$ various modifications are observed. Only three of them are mentioned (in the following shown with increasing stability): $\alpha<\varepsilon<\beta .^{[1,2,11]}$ In the modifications the molecules arrange in slightly different direction to the stacking axis (Figure 2). The thermodynamically most stable $\beta$ form shows a direct coordination of $\mathrm{Cu}^{\mathrm{II}}$ of a molecule to an $\mathrm{N}$ atom of an adjacent molecule within a stack. The angle of inclination of the macrocycles within a stack in the $\beta$-and also in the $\varepsilon$-forms is $\sim 45^{\circ}$. Neighboring stacks are arranged in a herring-bone style having close contacts between the $\pi$-system of one molecule and peripheral $\mathrm{H}$-atoms of adjacent stacks. This herring-bone interaction is edge-on-
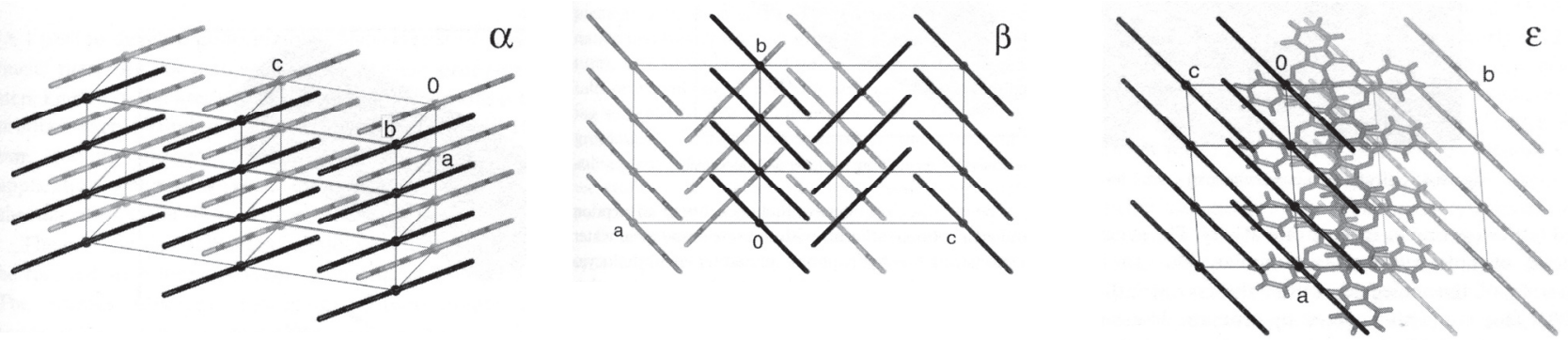

Figure 2. Crystal packing of the $\alpha, \beta$ and $\varepsilon$ polymorphic forms of CuPc. ${ }^{[2 a]}$ 
face in the $\beta$ and corner-on-face in the $\varepsilon$ form. The angle of inclination within the stacking axis in the $\alpha$ phase is $\sim 27^{\circ}$, and no herring-bone like interaction exists. In contrast to solution spectra in the solid state broad absorption bands, for example, of the $\alpha$ and $\beta$ phases (Figure 3) explain the different interaction possibilities within a staple and between staples. Thus, various modifications also absorb at different wavelengths: $\beta$ phase at $\lambda 625$ and $700 \mathrm{~nm}, \alpha$ phase at $\lambda 650$ and $750 \mathrm{~nm}$, and the still longer wavelength absorbing $\varepsilon$ phase at $\lambda<820 \mathrm{~nm}$ due to the before mentioned stronger

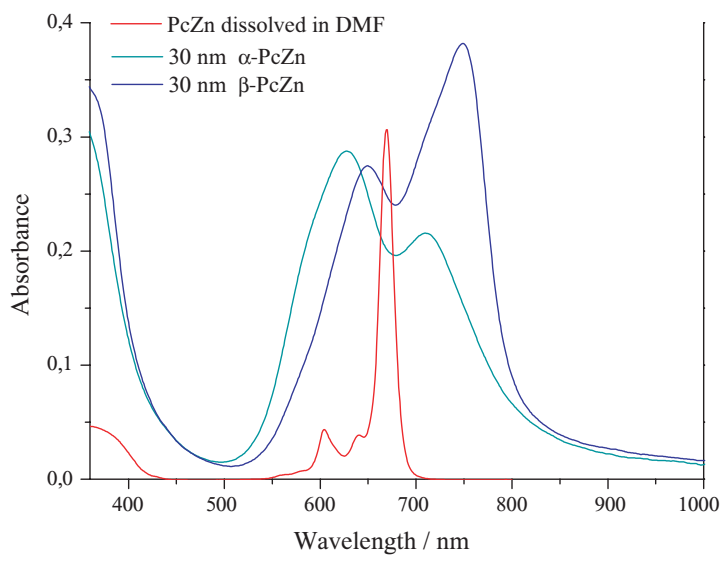

Figure 3. Absorption spectra of $\mathrm{ZnPc} 1$ in films of the $\alpha$ and $\beta$ modification in comparison to the solution spectrum (provided by D. Schlettwein, Universität Gießen, Germany). interaction between Pc molecules of adjacent stacks. The behaviour of phthalocyanines in the aggregated solid state is important for use as pigments, in LCD displays, in laser printers and organic solar cells.

The question is, how to get the individual modifications. ${ }^{[2,11]}$ The synthesis of Pcs at higher temperatures leads to the most thermostable $\beta$ phase with a particle size 5-100 $\mu \mathrm{m}$. Dissolving the $\beta$ phase in conc. sulfuric acid and precipitation with water or grinding in a ball mill in the presence of a salt such as $\mathrm{NaCl}$ results in the $\alpha$ phase with particle sizes from 30-50 nm. If unsubstituted Pcs are evaporated in vacuum or under inert gas, then microcrystalline films (film thicknesses from a few $\mathrm{nm}$ to $\sim 1 \mu \mathrm{m}$ ) at a substrate temperature of $\sim 25{ }^{\circ} \mathrm{C}$ the $\alpha$ and at $>200{ }^{\circ} \mathrm{C}$ the more stable $\beta$ modification is formed. Treating the $\alpha$ phase of $\mathrm{CuPc}$ in a mixer in the presence of an inorganic salt and an organic solvent results in only 20 to $30 \mathrm{~nm}$ rather round nanoparticles of the $\varepsilon$ modification (Figure 4A). ${ }^{[12]}$ Small particles of the $\varepsilon$ phase can be stabilized for long time storage by Shearing through a kneading process and adding of small amounts of dispersants such as surfactants (polyalkanolamines) or addition of small amounts (1-10\%) of CuPc with sulfonic acid or methylene phthalimide as substituents (Figure 4B). ${ }^{[2 a, b]}$ Nanoparticles are important in order to avoid light scattering and because the color intensity increases with smaller particle size. These brief remarks show that empirical evidence is also essential for the production of certain modifications which are important for the use as pigments or new materials.
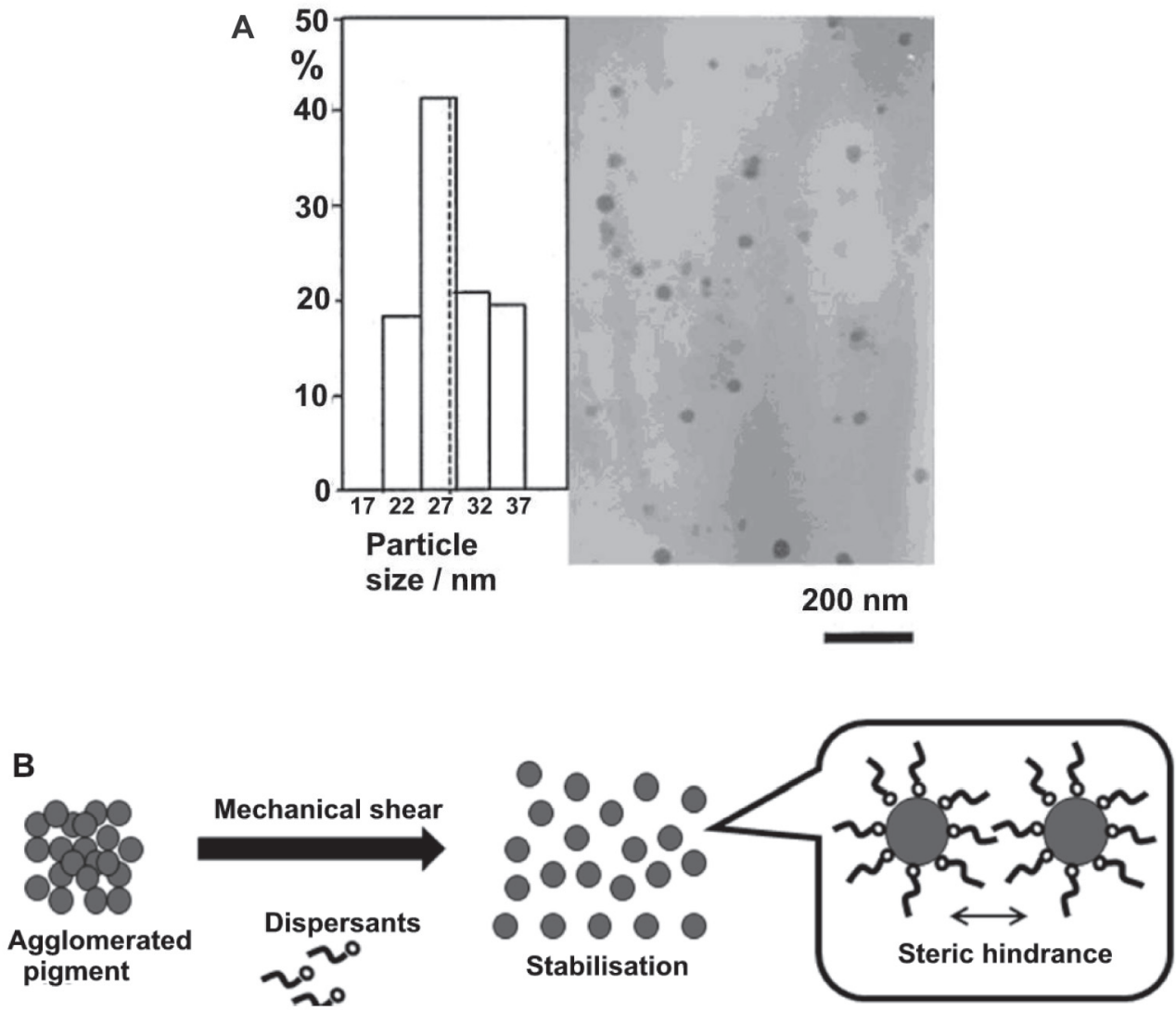

Figure 4. A) Nano particles of a metal phthalocyanine with a medium particle diameter of $26 \mathrm{~nm} \cdot{ }^{[12 a]}$ B) Process of formation and stabilization of nano particles. 
An important property of solid Pcs is the electrical conductivity $\sigma$. Surprisingly, Pcs cover over 20 orders of magnitude of conductivity (Figure 5). Several times sublimed MPcs $\left(\mathrm{M}=2 \mathrm{H}^{\mathrm{I}}, \mathrm{Cu}^{\mathrm{II}}, \mathrm{Zn}^{\mathrm{II}}, \mathrm{Ni}^{\mathrm{II}}\right.$, etc. $)$ at $25^{\circ} \mathrm{C}$ in vacuum exhibit intrinsic conductivities often like poor semiconductors till insulators of $10^{-7}$ to $10^{-14} \mathrm{~S} \cdot \mathrm{cm}^{-1} .^{[3,13]}$ The reason is that only weak intermolecular interactions exist because there is an intermolecular spacing of $\sim 0.34 \mathrm{~nm}$ between adjacent Pc molecules in the stacks of the crystals. Only very narrow energy bands are formed, and by thermal excitation charge carriers (electrons and holes) move driven by the electric field of the applied voltage by hopping through the potential field of the $\pi$-electron-rich aromatics. In the covalent lattice of the inorganic semiconductor $\mathrm{Si}$ the distances between the $\mathrm{Si}$ atoms are only $0.23 \mathrm{~nm}$, and $\sigma$ of the intrinsic $\mathrm{Si}$ is higher with $\sim 10^{-6} \mathrm{~S} \cdot \mathrm{cm}^{-1}$, therefore. The conductivity of the $\mathrm{p}$-conductor phthalocyanine is very sensitive against addition of chemical dopants. Under oxygen e.g. from the air, $\sigma$ increases, for example, for VOPc from below $10^{-10}$ to $5 \cdot 10^{-8} \mathrm{~S} \cdot \mathrm{cm}^{-1} \cdot{ }^{[13 \mathrm{c}, 14 \mathrm{a}-\mathrm{e}]} \mathrm{O}_{2}$ diffuses into the lattice of $\mathrm{Pc}$ and as electron acceptor takes over an electron from the $\mathrm{MPc}$, and the number of holes as charge carriers in the solid increases: $\mathrm{MPc}+\mathrm{O}_{2} \leftrightarrows \mathrm{MPc}^{+}+\mathrm{O}_{2}^{-}$. More efficient electron transfer proceeds by the addition of very strong organic electron acceptors such as highly fluorinated $\pi$-electron rich compounds (such as tetracyanotetrafluoroquinodimethane). [14e] By doping of MPcs with 1-5 mol\% of an acceptor $\sigma$ can increase from $\sim 10^{-10}$ to $\sim 10^{-2} \mathrm{~S} \cdot \mathrm{cm}^{-1[14 e, 15]}$ which is explained by increase of the number of holes as charge carriers from $\sim 10^{15}$ to $\sim 10^{19} \mathrm{~cm}^{3}$. The doping of organic semiconductors for use in organic solar cells is important. Even metallic conductivity can be achieved with phthalocyanines. ${ }^{[14 f]}$ One example is the partially oxidized NiPc. NiPc is heated with iodine in 1-chloronaphthalene. The resulting black crystals exhibit at room temperature $\sigma=5 \cdot 10^{2} \mathrm{~S} \mathrm{~cm}^{-1}$. With decreasing temperature the conductivity $\sigma$ increases and accounts at $5 \mathrm{~K}$ $\sim 10^{4} \mathrm{~S} \cdot \mathrm{cm}^{-1}$. This clearly demonstrates metallic conductivity. The problem for practical use is that the crystals are fragile, and that iodine can migrate out of the Pc crystal.

Another important solid state property of Pcs is the photoconductivity $\sigma_{\text {phot }}$ i.e. the increase of $\sigma$ under irradiation with visible light. ${ }^{[13 \mathrm{a}, 16]} \sigma_{\text {phot }}$, defined as the difference between $\sigma$ under irradiation and in the dark, follows the absorption spectrum of the films of Pcs, which means that by absorption of a photon an electron moves from the HOMO (valence band level) to the LUMO (conduction band level) and the number of negative and positve charge carries increase in the applied electrical field. For example, the conductivity of TiOPc increases up to $10^{4}$ orders of magnitude under irradiation. It was shown for doped VOPC that $\sigma$ increases three times under irradiation. ${ }^{[14]}$ The photoconductivity of MPcs is of practical importance in laser printers and copier machines.

One issue is the stability of the Pc under use. CuPc (1) can be sublimed under vacuum without decomposition at $\sim 500{ }^{\circ} \mathrm{C} .{ }^{[3]}$ The oxidative and photo-oxidative stability, i.e. in air is given up to $\sim 300{ }^{\circ} \mathrm{C}$. ${ }^{9 \mathrm{c}]}$

\section{Traditional Applications: Phthalocyanines as Colorants}

Color fastness, color uniformity, color intensity, color stability coupled with easy access are the conditions for the application of this large aromatic $\pi$-system as mentioned for colorants. Important as colorants are $\mathrm{Cu}^{\mathrm{II}} \mathrm{Pc}(\mathbf{1})$ and its derivatives $^{[2]}$ because they exhibit in the monomolecular dissolved or aggregated state a good chemical $\left(\mathrm{Cu}^{\mathrm{II}}\right.$ fits well in the ligand) and photochemical $\left(\mathrm{Cu}^{\mathrm{II}}\right.$ has in contrast to e.g. $\mathrm{Zn}^{\mathrm{II}}$ an open $d$ electron configuration and therefore bad photo-excited states).

The unsubstituted $\mathrm{CuPc}$ is used as most important blue pigment. As stated before, CuPc is obtained after the synthesis mostly as $\beta$ modification in a particle sizes of $>1 \mu \mathrm{m}$. By post-processing ("finishing") this $\mathrm{CuPc}$ can be converted into smaller particles and other modifications in order to obtain $\mathrm{CuPc}$ optimal for the application with suitable color strength, hue, flocculation stability and rheology. Figure 6 shows slightly different shades of $\alpha, \beta$ and $\varepsilon$ forms. Halogenated $\mathrm{CuPc}$ are important green pigments: $\mathrm{CuPcCl}_{\mathrm{x}}$ $(\mathrm{x}=14-15)$ bluish-green, $\mathrm{CuPcCl}_{\mathrm{x}} \mathrm{Br}_{\mathrm{y}}(\mathrm{x}=4-5, \mathrm{y}=11-12)$ yellowish-green. The use of various modifications as pigments in form of powders, pastes or suspensions is very wide for printing inks, paints, coatings, plastics, textiles, etc. The phthalocyanines are listed in the Colour Index ( $w w w$. colour-index.com/) with a particular classification.

Dyes are soluble colorants having an affinity to a substrate to be dyed, such as paper, textile fibre, leather, etc. Watersoluble phthalocyaninesulfonic acids contain statistically 2-4 sulfonic acid groups. They are used for dyeing cotton. Widely are also used sulfochlorides of $\mathrm{CuPc}$ which by reactions with various amines are converted in soluble sulfonamides. In some cases only part of the sulfonyl chloride groups are converted to sulfonamide groups, and the remainder of these groups are hydrolyzed to sulfonic acid groups resulting in amphoteric dyes that are insoluble in neutral water but soluble in alkaline and acidic aqueous solutions. Direct dyes are used

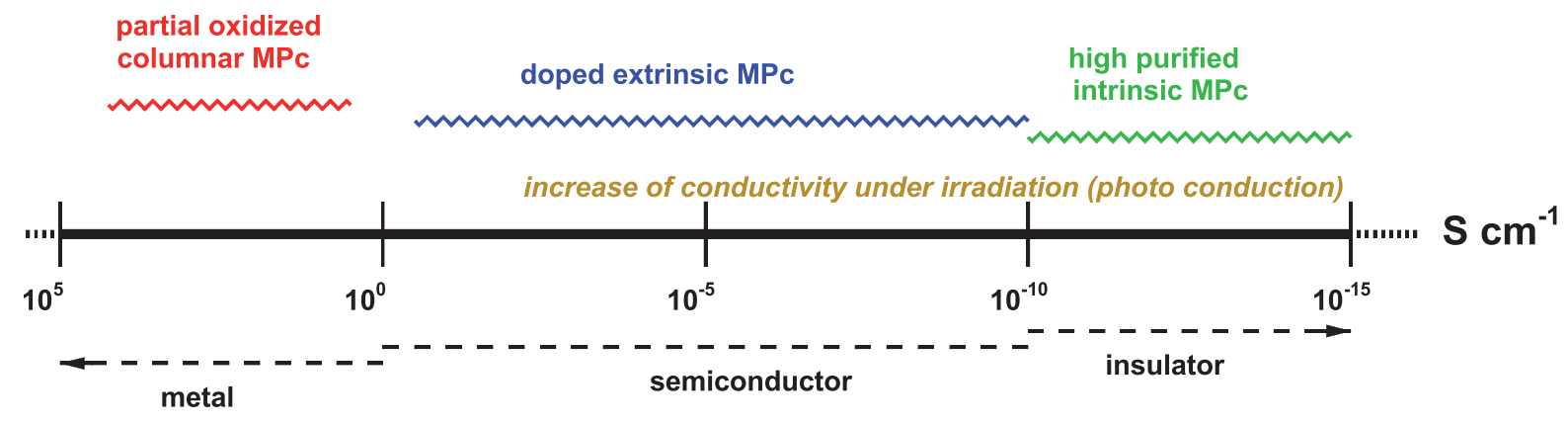

Figure 5. Conductivity range of phthalocyanines. 
$\alpha-\mathrm{CuPc}$

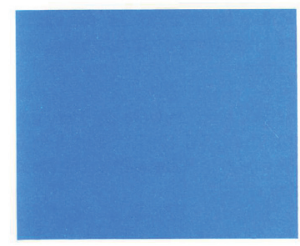

$\beta-C u P c$

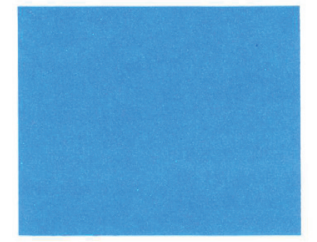

$\varepsilon-$ CuPc

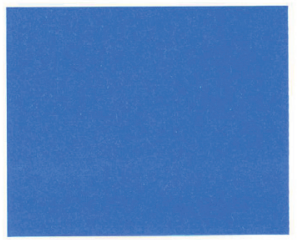

Halogeniertes CuPc

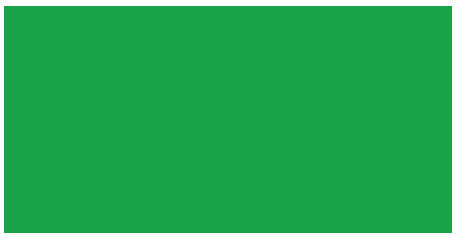

Figure 6. Color of films of different modifications of $\mathrm{CuPc} 1$ and a halogenated $\mathrm{CuPc}$.

in particular for the dyeing of cotton. Different reactive anchor group at the sulfonamide such as chlorotriazine can react with the HO-groups of the cellulose to form a covalent bond. A third important group is the chloromethylation of $\mathrm{CuPc}$. By subsequent reactions with amines, alcohols and phenols variously substituted soluble $\mathrm{CuPcs}$ are then produced.

\section{More Recent Applications: Phthalocyanines in Optical, Electronic and Photoelectronic Devices}

For the applications of Pcs in electronic and photoelectronic devices besides the optical absorptions additional properties as organic semiconductor and photoconductor are now important.

\section{Use in Recordable Disks (CD)}

Pre-recorded CDs (Compact Disk Digital Audio) came to the market in 1982. In subsequent years, the CD/ROM (read-only memory), the $\mathrm{CD} / \mathrm{R} /$ recordable (write once), the $\mathrm{CD} / \mathrm{RW}$ (ReWritable) were produced. Digital data on the disks exist in the form of small pits or changes on the surface which can be read with the laser. The change in the intensity of the reflected radiation is measured with a photodiode, and the binary information is converted via a digital-analog converter into an electrical signal. Pcs play a role in $\mathrm{CD} / \mathrm{Rs}$ which is therefore discussed in the following.

In Figure 7A one possible structure of a $\mathrm{CD} / \mathrm{R}$ in the sequence polycarbonate $\rightarrow$ dye $\rightarrow \mathrm{Ag} / \mathrm{Au}$ as reflective layer $\rightarrow$ paint protection film (lacquer coat) is shown. ${ }^{[17]}$ Irradiation is conducted with a laser at $\lambda 780 \mathrm{~nm}$. The layer thicknesses - including the altered layer thicknesses in the cavity (pregroove) - are chosen that in the non-recorded $\mathrm{CD} / \mathrm{R}$ after irradiation with a laser of $780 \mathrm{~nm}$ no attenuation of the reflected light occurs. In the "writing" process now, the rotating disk is irradiated with a high intensity laser beam along the pregoove, and the dye by absorption of photons is converted at first to an excited state. Some of the energy of the excited states will be disabled as heat. By this heat the dye is decomposed, forming bubbles, and it also slightly deforms the underlying polycarbonate. By this process on the once-burnt parts an information as so-called pit is located (Figure 7B). In the "reading" process with a low intensity laser a weakening of the reflection is observed. As result from the burning of the affected and non-affected areas of the pregoove a binary code 0 or 1 as a bit (eight bits of data are combined to 1 byte) exists.

The requirements for the dye are complex. As dyes besides phthalocyanines (golden colour of the $\mathrm{CD} / \mathrm{R}$ ) also cyanines (green/blue colour of the $\mathrm{CD} / \mathrm{R}$ ) and azo-metal complexes (dark blue colour of the $\mathrm{CD} / \mathrm{R}$ ) have gained importance. For MPcs (most stable against solar light) suitable substituents and suitable metal ions in the ligand must be selected. An example is the palladium(II) 1,8,15,22tetra(2,4-dimethyl-3-pentoxy)phthalocyanine 14 (only one positional isomer of $\mathbf{1 4}$ is shown):

- The PdPc 14 exhibits by the electron-donating effect of the alkoxy substituents the main absorption maximum ( $Q$ band) at $725 \mathrm{~nm}$ with a decrease in absorbance up to about $760 \mathrm{~nm}$. During the short time of the "writing" process some part of the dye is irreversibly destroyed, and during the "reading" process with a weak laser of $780 \mathrm{~nm}$ a pit on a pregroove can be detected by a decrease of the reflection. At $780 \mathrm{~nm}$ the not destroyed dye absorbs on the pregoove only weakly, while the largely black pit reduces the reflection.

- It is crucial to balance the temperature for the thermal decomposition of the dye which is also given by the intensity of the laser. The temperature should be above
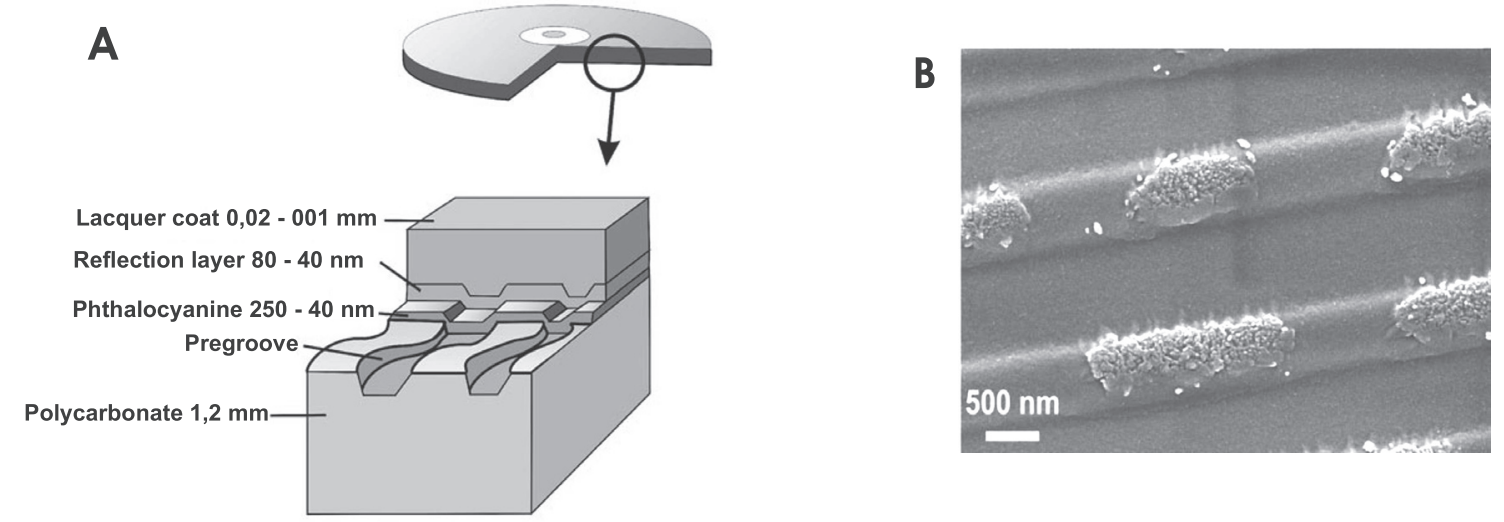

Figure 7. A) Configuration of a CD/R. B) Scanning electron micrograph of a data track. ${ }^{[17 b, c]}$ 


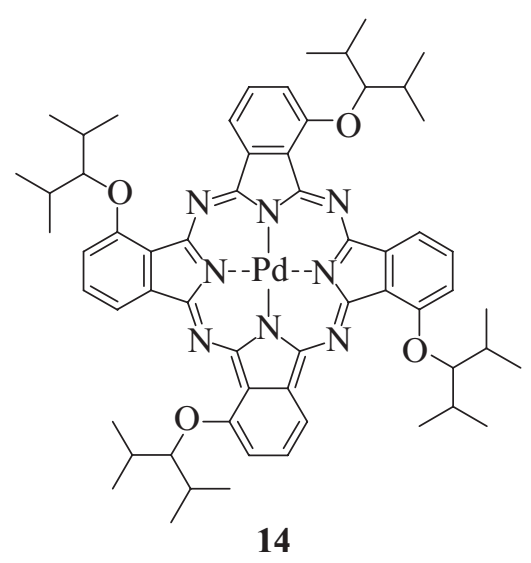

the softening temperature of $149{ }^{\circ} \mathrm{C}$ but below the melting temperature of $267^{\circ} \mathrm{C}$ of polycarbonate which will at higher temperature deform the polymer.

- The dye is applied from solution, and therefore dye must be readily soluble. After evaporation of the solvent the dye is not aggregated in the obtained film. In aggregates the excitation energy would be distributed from an excited molecule to non-excited molecules. The bulky substituents at the ligand lead to an even very good solubility and prevent in a solid thin film its aggregation.

- Other photophysical properties play a role. For the burning by excitation the dye should have a large absorption coefficient $\varepsilon$. This is for the PdPc 14 at $\lambda 720 \mathrm{~nm}$ $\sim 2 \cdot 10^{5} \mathrm{~L} \mathrm{~mol}^{-1} \mathrm{~cm}^{-1}$. The excited state should be deactivated efficient thermally and not disabled by luminescence. For $\mathrm{PdPc}$ the quantum yields of fluorescence and phosphorescence are only about $0.2 \%$ each, and the thermal deactivation is in the foreground.

\section{Use in Active Matrix Liquid Crystal Displays}

The development of liquid crystal displays (LCDs) began in the early $70^{\text {th }}$, led in the late $90^{\text {th }}$ to flat screens and from 2002 to flat television screens. In the LCDs MPcs display two of the three color components that are respon-sible for their intense color and absorption of visible light in certain wavelength ranges. First the structure of the active-matrix LCD displays which today consists in a matrix of thin-film transistors (TFT, thin film transistors) is described. ${ }^{[17 a, 18]}$
Starting from the side of the white light illumination the subsequent layers are as follows (Figure 8): polarizer 1 $\rightarrow$ glass substrate $\rightarrow$ alignment layer 1 (polyimide) $\rightarrow$ TFT layer for applying voltages $\rightarrow$ layer of a mixture of polar liquid crystals $\rightarrow$ alignment layer 2 (polyimide electrically charged with orientation of the electric field vector of the polymer molecules $90^{\circ}$ rotated to the orientation layer 1) $\rightarrow$ electrically conductive ITO layer $\rightarrow$ color filter layer $\rightarrow$ glass substrate $\rightarrow$ polarizer 2 (with the forward direction for light $90^{\circ}$ rotated to the polarizer 1$)$. The distance between the two glass plates is only a few $\mu \mathrm{m}$. Of particular importance are active matrix displays, which consist of a matrix-like arrangement of a series of rectangular submillimeter sized display elements (pixels) of the TFT layer. Each of these elements can be controlled independently from any other separately, for which purpose each serves a transistor. The opposite orientation of the electric field vector of the polyimide layers leads to a twist of the liquid crystals. The forward direction of the polarizers is respectively parallel to the orientation of the liquid crystals. This results in the described arrangement in a maximum transmission of the incident white light. With an applied voltage of approximately 2-3 V on the entire components, the liquid crystals are oriented parallel to the electric field that is they are not twisted. Then no light comes through, and the screen is black. With the help of transistors now small areas are driven by a small voltage with a black-white illustration. Important is a ms switching times in TFTs below $20 \mathrm{~ms}$.

How is the color in the display possible? A color layer (color filter) consists of a two-dimensional periodic arrays of color absorptive surfaces in the three primary colors red, green and blue of the additive color mixture. All colors can be represented including white and black (Figure 9). A pixel now contains subpixel for each of the three primary colors, which are also driven separately by a transistor. For large-scale LCD monitors in HD resolution for 25 million addressable points also 25 million transistors must be available! To the colorants of the three primary colors particular requirements are addressed: color fastness, color uniformity, color intensity, color stability. To avoid light scattering, the colorants must be present as nanoparticles of about 20 to $30 \mathrm{~nm}$ in uniform and globular form that do not grow together to form agglomerates. To meet these demands, the development of suitable nano-pigments was required.

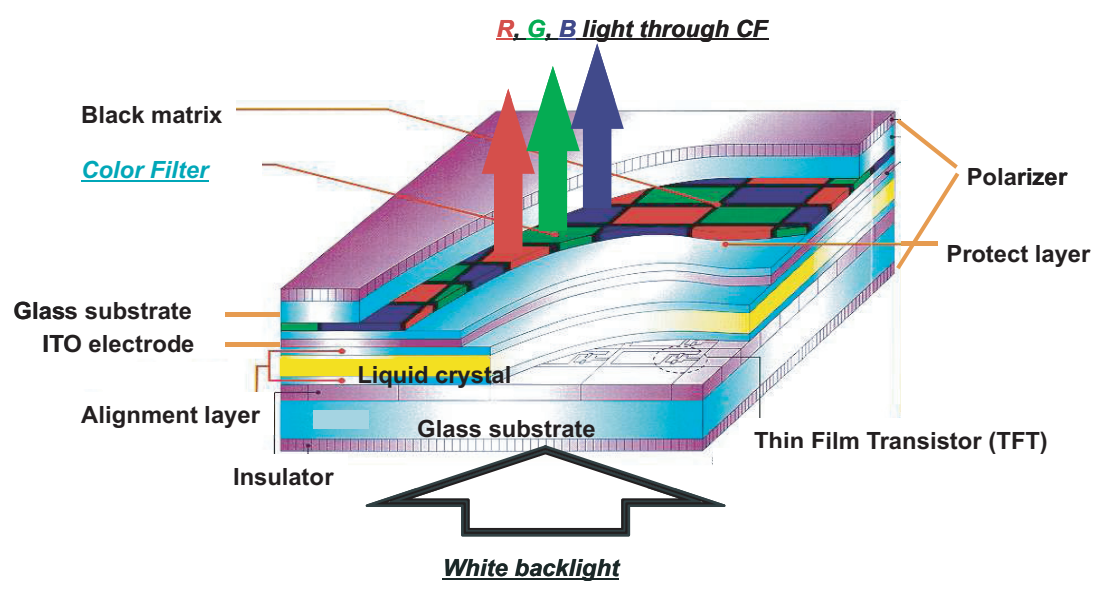

Figure 8. Configuration of an LCD display. 
It was found that phthalocyanines cover two of the three primary colors. For the primary color blue the $\varepsilon$ modification of $\mathrm{CuPc} \mathbf{1}$ is employed. For the primary color green the halogenated $\mathrm{CuPcCl}{ }_{\sim 4} \mathrm{Br}_{\sim 12}$ is appropriate. For the color red, e.g. diketopyrrolopyrrole (DPP), are used.

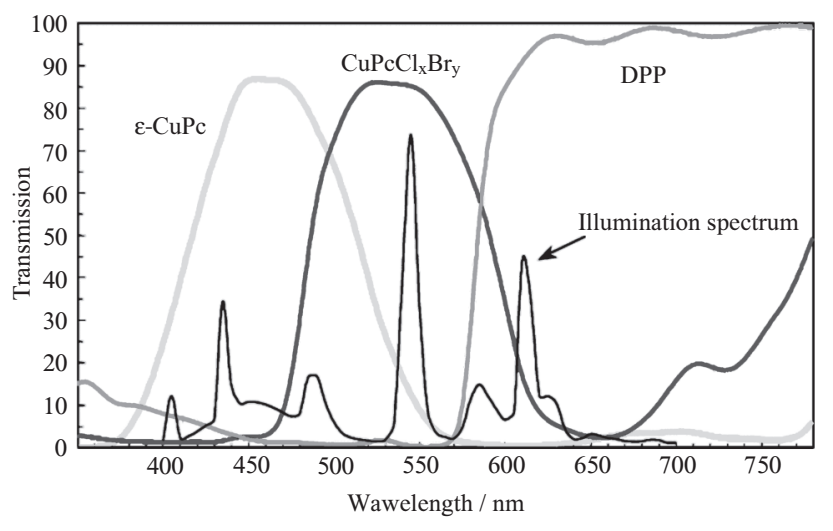

Figure 9. Transmission of the three fundamental colors red, green and blue of an LCD display.

\section{Use as Photoconductors in Laser Printers}

The first copy machine (procedures called electrophotography or xerography) came to market in 1950 , and 1973 the first color copier was introduced. Today the indirect dry method of xerography is technically very advanced. The essence of the xerographic process is to produce an electrostatic image under illumination of a photoconductor and then make a template to develop a positive image of the original on a printout.

The core of the device is a light-sensitive photoconductor. ${ }^{[12 b, 16 e, 17 a, 19]}$ Today, more than $90 \%$ organic photoconductors based on the $Y$-modification of titanyl phthalocyanine ( $\mathrm{TiOPc}$; to understand: $\mathrm{Pc}^{2-}, \mathrm{Ti}^{4+}$ and $\mathrm{O}^{2-}$ bound, i.e. $\left.(\mathrm{Ti}=\mathrm{O})^{2+} \mathrm{Pc}^{2-}\right)$ is used. Advantages of low cost TiOPc are: very good photoconductivity, excellent photostability, absorption of light in the long wavelength visible region with high absorbance. Irradiation is carried out with an efficient, compact and inexpensive GaAs diode laser or LEDs that emit at about 780-800 nm light. The photoconductive TiOPc absorbs in this wavelength range with a quantum yield close to 1 (i.e. almost $100 \%$ ). During the xerographic process the absorbed light is converted into charge carriers. The following process steps are distinguished (Figure 10):

a) Corona charging of the active photoconductive layer: An aluminum foil on a drum is loaded with the double layer of a photoreceptor which consists of a 0.2 to $2 \mu \mathrm{m}$ thick film of a charge carrier generation layer (CGL) followed by a 15 to $30 \mu \mathrm{m}$ thick film of a charge carrier transport layer (CTL). [16a,e] CGL is composed of nano particles of the $Y$ modofication of TiOPc. CTL is, for example, poly $(N$-vinylcarbazole $)$ or a polymer such as polycarbonate or poly(vinylbutyral) in mixture with tertiary aromatic amines which are easily oxidizable, and therefore act as hole conductors. First, the drum is electrostatically charged by a DC voltage of about $5-10 \mathrm{kV}$. Because of the low electrical dark conductivity of the TiOPc $\left(\sigma<10^{-10} \mathrm{~S} \mathrm{~cm}^{-1}\right)$ the charge remains in the dark.

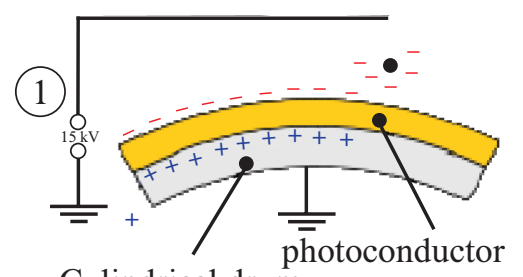

Cylindrical drum Light

(2)

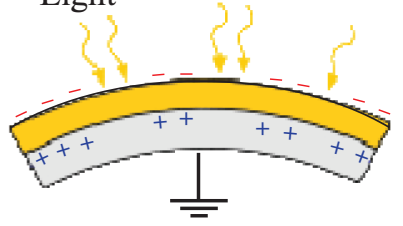

(3)
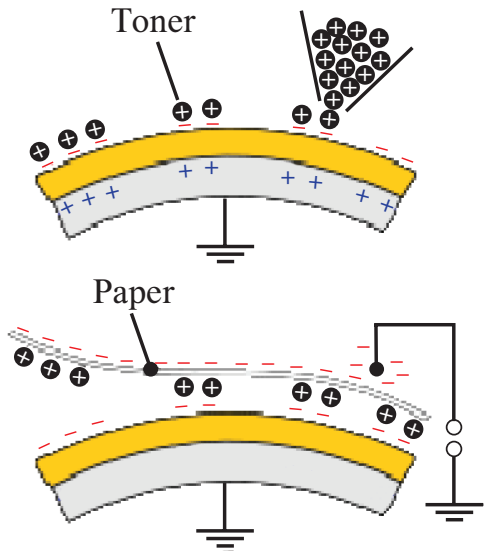

Figure 10. Schematic presentation of the xerographic process: 1) Charging. 2) Irradiation. 3) Toner transfer. 4) Development of copy toner transfer onto the print medium and fixation.

b) Processes involved in the exposure of a black/white original: In the case of laser printers and digital copiers the reflected light of an original to be copied is at first taken up by a line sensor (similar to a scanner). Then it is digitized and directed line by line with a laser or an LED line array onto the drum, and thereby with a grid pattern switched on or off. At the dark places of the original the charges remain. On the other hand, the bright areas of the original will discharge the CGL/CTL layer (Figure 11). Under irradation of the photoconductor TiOPc ${ }^{[14 c ; 16 a, d, e]}$ an electron $\left(\mathrm{e}^{-}\right)$- hole $\left(\mathrm{h}^{+}\right)$pair (exciton) is generated. Through the presence of the acceptor $\mathrm{O}_{2}$ from air an electron transfer from the excited $\mathrm{TiOPc}$ toO occurs, and thus a recombination of $\mathrm{e}^{-}$and $\mathrm{h}^{+}$to the ground state of TiOPc is avoided. The remaining hole in the strong electric field now moves through the hole conducting CTL layer and unloads the negative electrostatic charges on the surface of the CTL layer. Conversely, existing negative charges are discharged on the inside of the CGL. Gray scales are achieved by weakening of the exposure. The latent image thus consists of charge-free or partially charge-free zones.

c) Development of toner transfers onto the print medium and fixation: A powdery, dry toner (particle size of a common one-component toner 3-15 $\mu \mathrm{m}$, consisting of developers, a fusible plastic and a magnetic metal oxide) is transferred due to electrostatic attractions and remains at the unexposed charged sites of the photoconductor drum stick. For transferring the toner image from the drum to the printed medium, this side is electrostatically charged by a second charge source of about $15 \mathrm{kV}$. Then due to positive charges it can take up the toner particles. By heating to 


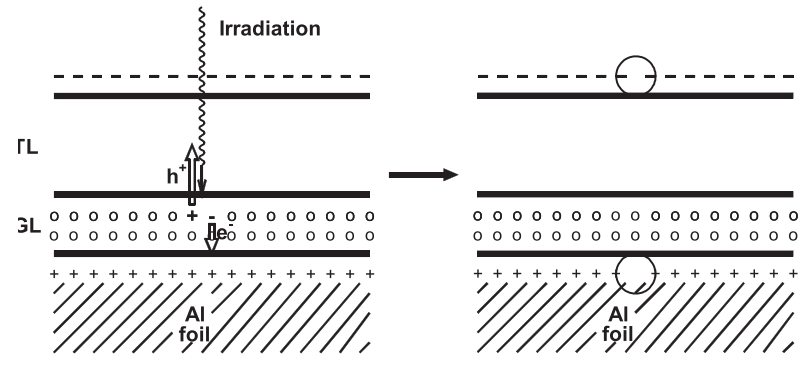

Figure 11. Photo discharge of the photo receptor.

$165-190{ }^{\circ} \mathrm{C}$ the polymer in the fixed toner particle melts and fixes the developer image. Further, the photoconductor drum is unloaded. The photoconductor drum exhibits with approximately 50000 copies a fairly long life time.

d) Color laser printer: The new generation of color laser printers have four colors (cyan, magenta, yellow and black) which are transferred from four individual printing units. Cyan, magenta and yellow are the primary colors of the subtractive color mixing. Simple full-color printing systems print the medium in four passes. For each pixel a grid of $8 \sim 8$ i.e. 64 pressure points is printed in order to obtain the desired color image, which reduces the resolution (the physical resolution of $2400 \mathrm{dpi}$ is reduced by a factor of 8 to $300 \mathrm{dpi}$ ). In another method with better resolution individual colors printed on each other and mixed during fixing. For the colors also phthalocyanines are important. The $\beta$-modification of the $\mathrm{CuPc} \mathbf{1}$ is used as cyan.

Titanyl phthalocyanine exists in various modifications, of which the $Y$-phase is the best photoconductor ${ }^{[14 \mathrm{c} ; 16 \mathrm{a}, \mathrm{d}, \mathrm{e} ; 19]}$ It is prepared by the reaction of titanium(IV)tetrabutoxide and 1,3-diimino isoindolenine (5) followed by acid-and solvent treatment. ${ }^{[5 b, 20]}$ Crucial for a very good photoconductivity of organic materials is the arrangement of the MPc molecules in nanoparticles to each other. In addition to the long-wavelength absorption an efficient photoconductor should exhibit a large charge carrier mobility in the excited state, short intermolecular distances between neighboring molecules $(\sim 0.35 \mathrm{~nm})$ and good intermolecular charge transfer interaction. The X-ray structure of Y-TiOPc is unusual. ${ }^{[21]} \mathrm{In}$ comparison to $\mathrm{CuPc}$ the $\mathrm{Pc}^{2-}$ ligand in TiOPc is slightly bent, and the $(\mathrm{Ti}=\mathrm{O})^{2+}$ projects axially from the ligand (Figure 12 left). Each molecule in the solid state overlaps with four molecules of the neighboring layer (Figure 12 right). As a result under illumination in the electric field of the applied voltage a good charge transfer, in which also the axial, negatively polarized oxygen plays a role, is given.

\section{Use in Organic Solar Cells (OPV)}

Photovoltaic solar cells made from $p$-and $n$-type silicon have commercialy efficiencies of 15 to $20 \%$ and gains great importance for the conversion of solar energy into electrical energy. In 2011 module costs were US\$ $1.25 \mathrm{~W}^{-1}$. It is expected that also organic solar/photovoltaic cells (OPV) will soon be available. From about the beginning of the $1990^{\text {th }}$ first scientific publications appeared with low efficiencies of the cells of that time $(\sim 1 \%)$. At present about $10-12 \%$ efficiencies are achieved under laboratory conditions and $\sim 7-9 \%$ are possible at present for greater modules. It is expected that with $10 \%$ efficient modules costs will be only US $\$ \sim 0.30$ $\mathrm{W}^{-1}{ }^{[22]}$ Therefore electrical energy from organic solar cells will be less expensive. In OPVs the organic semiconductor phthalocyanine is from the beginning in the $1990^{\text {th }}$ one of the active components. Phthalocyanines exhibit the following useful properties for OPVs: high crystalline order in the solid state, $p$-conductivity, photoconductivity, absorption in the visible range with a large extinction coefficients, right position of electronic energy levels, good photostability.

Figure 13 shows schematically the configuration of a single heterojunction "pin" cell. ${ }^{[15]}$ In this cell type " $\mathrm{i}$ " is the intrinsic absorber layer for visible light consisting of $\mathrm{ZnPc}$ or $\mathrm{CuPc}(\mathbf{1})$ as p-type and $\mathrm{C}_{60}$ (fullerene) as $n$-type conductor. Also 1,8,15,22-tetrafluorophthalocyanine can act as absorber and $p$-conductor, ${ }^{[23 a]}$ and hexadecafluorophthalocyanine is employed as absorber and $n$-conductor. ${ }^{[23 b]}$ Starting from the side of the illumination with visible light the order of the layers is often in a "pin" cell as follows: glass (can be also PET for flexible cells) covered with the inorganic semiconductor ITO as anode ( $\sim 90 \%$ transparent for visible light) $\rightarrow$ hole transporting layer (for example MeOTPD $\left(N, N, N^{\prime}, N^{\prime}\right.$-tetrakis(4-methoxyphenyl)benzidine) $\rightarrow \mathrm{ZnPc}$ or $\mathrm{CuPc}$ (1) (as p-conductor, often doped with an organic acceptor to increase the conductivity), partly in mixture with $\mathrm{C}_{60} \rightarrow \mathrm{C}_{60}$ (as $n$-conductor) $\rightarrow$ electon conducting layer $\left(n-\mathrm{C}_{60}\right.$, doped with an organic donor) $\rightarrow \mathrm{Al}$ as cathode (also for reflection of light).
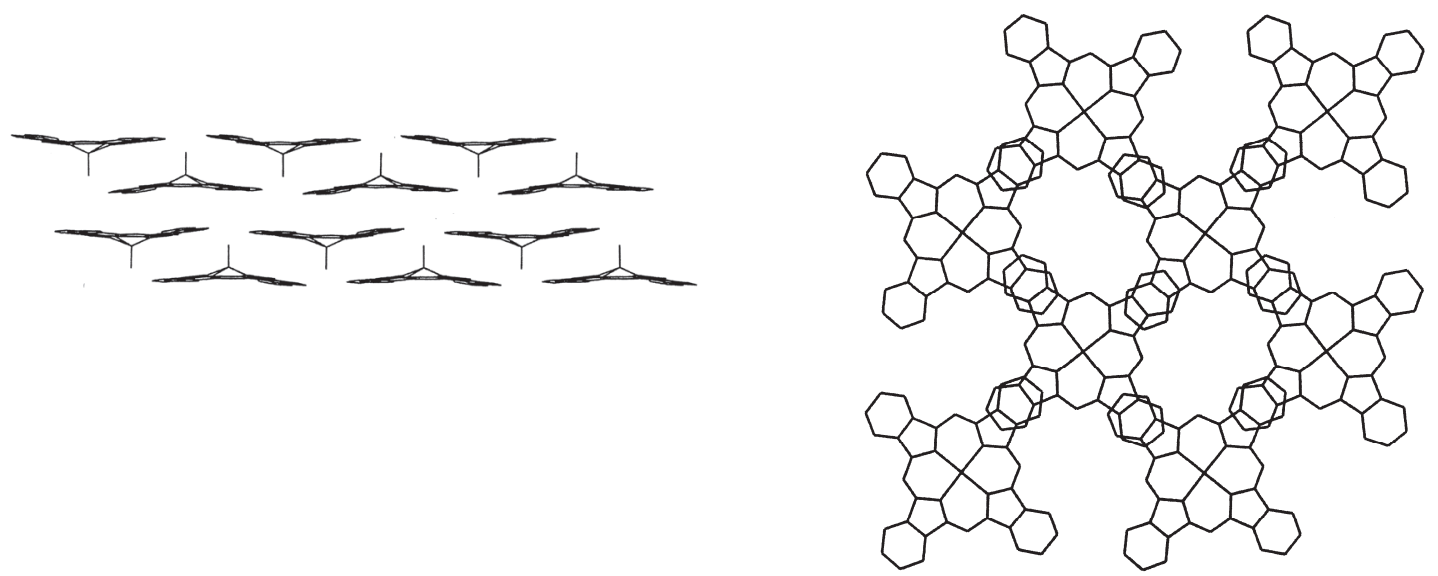

Figure 12. Crystal structure of $Y$-TiOPc. ${ }^{[21 a]}$ 


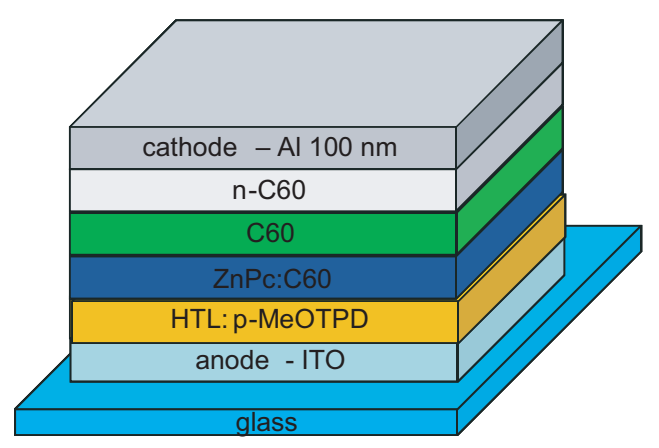

Figure 13. Configuration of a single heterojunction "pin" cell.

The organic layers are prepared mainly by vacuum evaporation. The organic semiconductors absorb part of the visible light: $\mathrm{ZnPc}$ at $\lambda \sim 550$ to $750 \mathrm{~nm}$ and $\mathrm{C}_{60}$ at $\lambda \sim 420$ to 470 $\mathrm{nm}$. Under excitation of the organic semiconductors, electrons move from the HOMO to the LUMO, and electron-hole pairs (exciton) are obtained. In the electrical field then electrons move in the direction of lower energy for them to the $\mathrm{Al}$ electrode (cathode), and holes move in the direction of lower energy for them to the ITO electrode (Figure 14). In order to avoid that a part of the electrons do not move in the direction of the anode (electrons should move only to the $\mathrm{Al}$ cathode) on the anode side a thin hole transporting layer (HTL) an tert. aromatic amine such as MeOTPD is located, which locks against electrons. Conversely, on the cathode side, an electron transporting layer, such as doped $\mathrm{C}_{60}$ can be located, which blocks to holes (holes should move only to the ITO anode).

In order that holes and electrons are quickly separated and do not recombine in the light absorbing layers, the layer thicknesses of the individual materials are only 50 to 100 $\mathrm{nm}$. In this "pin" arragement, partly with additional compounds, efficiencies up to $\sim 4 \%$ were determined. ${ }^{[22 a, c]}$ In "tandem" cells two "pin" cells are stacked in series connection on each other in order to absorb more incident light. They are prepared by stepwise evaporation of the individual compounds on the conductive support ITO on glass or PET. In the "tandem" arrangement an increase of the efficien-

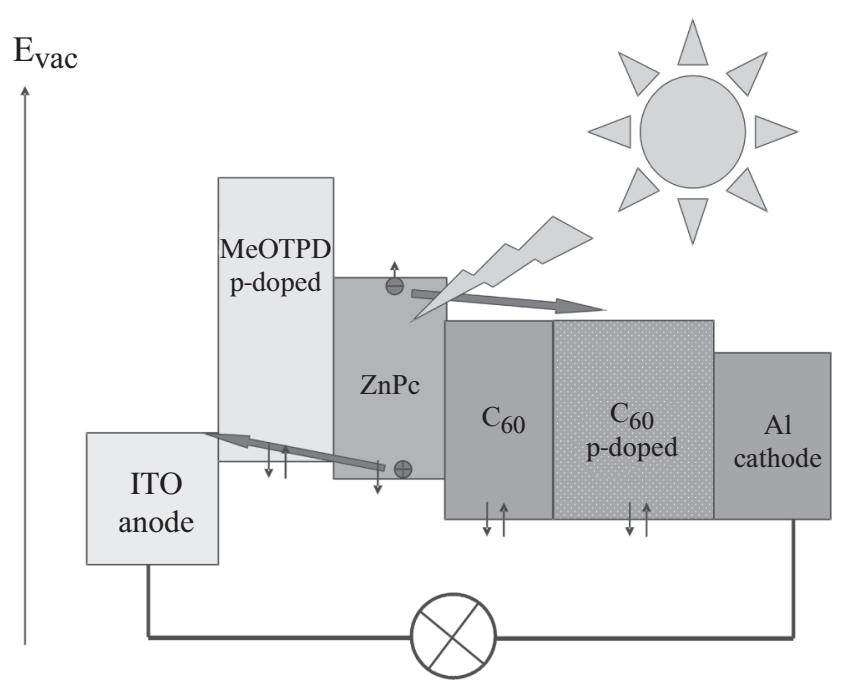

Figure 14. Schematic energy diagramm of a single heterojunction "pin" cell including electron and hole flow after irradiation and exitation. cies up to $\sim 6.5 \%$ were obtained. ${ }^{[23 a, d]}$ Recently the Heliatek company announced for a "tandem" cell an certificated efficiency of $10.7 \%{ }^{[23 e]}$ Some advantages of organic solar cells are: High efficiency are obtained also at low light intensity; environmental friendly materials are used; low material requirements $\left(\sim 1 \mathrm{~g} / \mathrm{m}^{2}\right)$ are only necessary; inexpensive production processes (roll to roll) are applied.

\section{Further, Potential Applications}

Phthalocyanines can find applications in other areas: for the catalytic mercaptan oxidation process of gasoline fractions of petroleum with CoPc (MEROX process), ${ }^{[24]}$ FePc derivatives as deodorant for odor removal, ${ }^{[17 c, 25]}$ sensitizers in photodynamic tumor therapy. ${ }^{[17 c, 26]}$ For other applications in different area phthalocyanines are employed but the state is difficult to evaluate, since applied works are often carried out in companies. Examples are:[27] non-linear optical devices such as optical-limiting, ${ }^{[28]}$ organic light emitting diodes (optoelectronic device), ${ }^{[29]}$ organic field effect transistors (electronic component), ${ }^{[30]}$ dye sensitized solar cells. ${ }^{[31]}$ Potential applications of phthalocyanines as materials on the nanometer scale and in combination with nano-structured systems are envisaged. ${ }^{[32,33]}$ Very interesting for applications in the NIR are azulenocyanines which are absorbing from the visible region till $\sim 1200 \mathrm{~nm} .^{[8 \mathrm{c}]}$

\section{References}

1. a) McKeown N.B. Phthalocyanine Materials, Cambridge University Press, 1998. b) Polley R., Heckmann H., Hanack M. Methods of Organic Chemistry (Houben-Weyl), 4 Edition, Vol. E9, Georg Thieme Verlag, Stuttgart, 1997. 717-842. c) The Porphyrin Handbook [Kadish K.M., Smith K.M., Guilard R., Eds.] Vol. 15-20, Elsevier Science, San Diego, 2003.

2. a) Erk P., Engelsberg H. Phthalocyanines Dyes and Pigments. In: The Porphyrin Handbook [Kadish K.M., Smith K.M., Guilard R., Eds.] Vol 19, Elsevier Science, San Diego, 2003. 105-149. b) Löbbert G. Phthalocyanines, Ullmann's Encyclopedia of Industrial Chemistry, Vol. A 20, VCH Publishers, Weinheim, 1992. 213-241. c) Wöhrle D., Schnurpfeil G., Makarov S., Suvorova O. Chemie in Unserer Zeit 2012, 46, 12-24.

3. Brinkmann H., Kelting C., Makarov S., Tsaryova O., Schnurpfeil G., Wöhrle D., Schlettwein D. Phys. Status Solidi A 2008, 205, 409-420.

4. a) Wöhrle D., Schnurpfeil G., Knothe G. Dyes Pigm. 1992, 18, 91-102. b) Shinohara H., Tsaryova O., Schnurpfeil G., Wöhrle D. J. Photochem. Photobiol. A: Chem. 2006, 184, 50-57. c) Kliesch H., Weitemeyer A., Müller S., Wöhrle D. Liebigs Ann. 1995, 1269-1273. d) Michelsen U., Kliesch H., Schnurpfeil G., Sobbi A.K., Wöhrle D. Photochem. Photobiol. 1996, 64, 694701. e) Gerdes R., Lapok L., Tsaryova O., Wöhrle D., Gorun S.M. Dalton Trans. 2009, 1098-1100.

5. a) Yüksek M., Elmali A., Durmus M., Ünver H., Nyokong T. $J$. Opt. 2010, 12, 015208. b) Mantareva V., Kussovski V., Angelov I., Wöhrle D., Dimitrov R., Popova E. Photochem. Photobiol. Sci. 2011, 10, 91-102. c) Chen Y., Subramanian L.R., Barthel M., Hanack M. Eur. J. Inorg. Chem. 2002, 1032-1034. d) Mantareva V., Angelov I., Kussovski V., Dimitrov R., Lapok L., Wöhrle D. Eur. J. Med. Chem. 2011, 46, 4430-4440. e) Lapok L., Schnurpfeil G., Gerdes R., Gorun S.M., Suvorova O., Wöhrle D. J. Porphyrins Phthalocyanines 2009, 13, 346-357.

6. a) Uchida H., Tanaka H., Reddy P.Y., Nakamuru S., Toru T. Synth. Lett. 2002, 10, 1649. b) Mikhalenko S.A., Barknova S.V., 
Lebedev O.L., Luk'yanets E.A. J. Gen. Chem. USSR 1971, 41, 2770. c) Opis D.M., Nuesch F., Loewe C., Molberg M., Nagel M. Chem. Mater. 2008, 20, 6889-6896. d) Tylleman B., Gomez-Aspe R., Gbabode G., Sergeyev S. Tetrahedron 2008, 64, 4155-4161. e) Mantareva V., Petrova B., Avramov L., Angelov I., Wöhrle D. J. Porphyrins Phthalocyanines 2005, 9, 947-953. f) Cook M.J., Dunn A.J., Howe S.D., Harrison K.J. J. Chem. Soc. Perkin Trans I 1988, 2453-2458. g) Mashazi P., Antunnes E., Nyokong T. $J$. Porphyrins Phthalocyanines 2010, 14, 932-947. h) Wöhrle D., Meyer G., Wahl B. Makromol. Chem. 1980, 181, $2127-2135$.

7. a) Rager C., Schmid G., Hanack M. Chem. Eur. J. 1999, 5, 280 288. b) Görler B., Dachtler M., Glaser T., Albert K., Hanack M. Chem. Eur. J. 2001, 7, 2459-2465.

8. a) Kobayashi N. In: The Porphyrin Handbook, Vol. 15 [Kadish K.M., Smith K.M., Guilard R., Eds.], Academic Press, San Diego, California, 2003. 161-262. b) Rio Y., RodriguezMorgade M.S., Torres T. Org. Biomol. Chem.2009, 6, 18771894. c) Muranaka A., Yonehara M., Uchiyama M. J. Am. Chem. Soc. 2010, 132, 7844-7845. d) Kobayashi N., Nakajima S., Ogata H., Fukuda T. Chem. Eur. J. 2004, 10, 6294-6312. e) Claessens C.G., Gonzales-Rodriguez D., Torres T. Chem. Rev. 2002, 102, 835-853. f) Marks T.J., Stojakovic D.R. J. Am. Chem. Soc. 1978, 100, 1695-1705. g) Silver J., Jassim Q.A. Inorg. Chim. Acta 1988, 144, 281-288. h) Weiss R., Fischer J. In: The Porphyrin Handbook, Vol. 16 [Kadish K.M., Smith K.M., Guilard R., Eds.], Academic Press, San Diego, California, 2003. 171-246.

9. a) Schnurpfeil G., Sobbi A.K., Spiller W., Wöhrle D. J. Porphyrins Phthalocyanines 1997, 1, 159-167. b). Sobbi A.K., Wöhrle D., Schlettwein D. J. Chem. Soc. Perkin Trans. 2 1993, 481-488. c) Wöhrle D., Schulte B. Makromol. Chem. 1985, 186, 2229-2245.

10. a) Makarov S.G., Suvorova O.N., Wöhrle D. Eur. J. Inorg. Chem. 2007, 546-552. b) ibid J. Porphyrins Phthalocyanines 2011, 15, 791-808. c) Tolbin A.Yu., Tomilova L.G., Zefirov N.S. Russ. Chem. Rev. 2008, 77, 435-449.

11. Kment S., Kluson P., Drobek M., Gregora G., Hubicka Z. Thin Solid Films 2009, 517, 5274-5270.

12. a) Wang Y. J Colloid Interface Sci. 1999, 213, 270-272. b) Wang Y., Liang D. Adv. Mater. 2010, 22, 1521-1525. c) Kim E., Jung K.-S., Kim J.G., Paik H. Polymer (Korea) 2012, 36, 104-110. d) Hayashi K., Iwasaki K., Horie S., Ichimura K. J. Mater. Chem. 2007, 17, 527-530.

13. a) Dini D., Hanack M. In: The Porphyrin Handbook, Vol. 17, [Kadish K.M., Smith K.M., Guilard R., Eds.], Academic Press, San Diego, California, 2003. 1-36. b) Seoudi R., El-Bahy G.S., El Sayed Z.A. J. Mol. Struct. 2005, 753, 119-126. c) Saleh A.M., Hassan A.K., Gould R.D. J. Phys. Chem. Solids 2003, 64, 1297-1303. d) Rajesh K.R., Menon C.S. Eur. Phys. J. B 2005, 47, 171-176. e) Saleh A.M., Abu-Hilal A.O., Gould R.D. Curr. Appl. Phys. 2003, 3, 345-350

14. a) Zhou Q., Gould R.D. Thin Solid Films 1998, 317, 432-435. b) Hassan A.K., Gould R.D. Intern J. Electr. 1990, 69, 11-17. c) Nishi T., Kanal K., Willis M.R., Seki K. Mol. Cryst. Liq. Cryst. 2006, 455, 227-233. d) Trogler W.C. Structure and Bonding 2012, 142, 91-118. e) Pfeiffer F., Leo K., Schlettwein H.S., Wöhrle D. Sol. Energy Mater. Sol. Cells 2000, 63, 83-99. f) Inabe T., Tajima H. Chem. Rev. 2004, 104, 5503-5534.

15. Walzer K., Maennig B., Pfeiffer M., Leo K. Chem. Rev. 2007, 107, 1233-1271.

16. a) Popovic Z.D., Hor A. Mol. Cryst. Liq. Cryst. 1993, 228, 75-80. b) Miles J.R., Willis M.R., Jones R.P.O. Mater. Sci. Semicond. Process. 2012, 15, 61-72. c) Xavier F.P., Goldsmith G.J. Bull. Mater. Sci. 1995, 18, 269-275. d) Yamaguchi S.,
Sasaki Y. Chem. Phys. Lett. 2000, 323, 35-42. e) Tong L.-F., Li L.-W., Zheng Q. J. Mater. Sci. Lett. 2003, 22, 1763-1765.

17. a) Tanaka M. In: High Performance Pigments [Faulkner E.B., Schwartz R.J., Eds.] Wiley-VCH: Weinheim, 2009. 275-292. b) Mustroph H., Stollenwerk M., Bressau V. Angew. Chem. 2006, 118, 2068-2087. c) Roth K. Chemie in Unserer Zeit 2007, 41, 334-345. d) www.ecma-international.org/publications/files/ ECMA-ST/ECMA-394.pdf. e) www.cd-info.com.

18. a) Choi J., Kim S.H., Yoon C., Kim J.P. New J. Chem. 2012 36, 812-818. b) Kim Y.D., Kim J.P., Kwon O.S., Cho I.H. Dyes and Pigments 2009, 81, 45-52 c) Römer M., Becker W. Chemie in Unserer Zeit 2009, 43, 94-99. d) Hoogboom H., Rasing T., Rowan A.E., Nolte R.M.J. J. Mater. Chem. 2006, 16, 1305-1314. e) For demonstration of LCD displays: www. techtower.de , then click „Infothek“ $\rightarrow$,Labor-Archiv“ $\rightarrow$,Alle Experimente auf einen Blick“".

19. a) Law K.-Y. Chem. Rev. 1993, 93, 449-486. b) Lee J.D., Kim H.B. Korean J. Chem. Eng. 2009, 26, 673-678.

20. a) Nalwa H.S., Iwayanagi T. J. Phys. Chem. 1993, 97, 1051510517. b) Mizaguchi J., Karfunkel H.R. J. Phys. Chem. 1995, 99, 16217-16227.

21. a) Engel M.K. In: The Porphyrin Handbook, Vol. 20 [Kadish K.M., Smith K.M., Guilard R., Eds.], Academic Press: San Diego, 2003. 58. b) Oka K., Okada O., Nukada K. Jpn. J. Appl. Phys. 1992, 31, 2181.

22. Hardin B.E., Snaith H.J., McGehee M.D. Nat. Photonics 2012 , 6, 162-169.

23. a) Riede M., Uhrich C., Widmer J., Timmreck R., Schwartz G., Gnehr, M.-M., Hildebrandt D., Hwang J., Sundarraj S., Erk P., Pfeiffer M., Leo K. Adv. Funct Mater. 2011, 21, 3019-3028. b) Opitz A., Ecker B., Wagner J., Hinderhofer A., Schreiber F., Manara J., Pflaum J., Brütting W. Org. Electron. 2009, 10, 1259-1267. c) Xue J., Rand B.P., Uchida S., Forrest R. Adv. Mater. 2005, 17, 66-71. d) Xue J., Rand B.P., Uchida S., Forrest R. Appl. Phys. Lett. 2004, 85, 5757-5759. e) www.heliatek. com.

24. a) Wöhrle D., Suvorova O., Gerdes R., Bartels O., Lapok L., Baziakina N., Makarov S., Slodek A. J. Porphyrins Phthalocyanines 2004, 8, 1020-1041. b) Sharipov A.K., Kortunenko S.V. Petroleum Chemistry [Neftekhimiya] 1997, 37,558 .

25. Kimura M., Shirai H. In: The Porphyrin Handbook, Vol 19, [Kadish K.M., Smith K.M., Guilard R., Eds.], Elsevier Science, San Diego, 2003. 151-178.

26. a) Hirth A., Michelsen U., Wöhrle D. Chemie in Unserer Zeit 1999, 33, 84-94. b) Lukyanets E.A. J. Porphyrins Phthalocyanines 1999, 3, 424-432.

27. Several articles in Structure and Bonding 2010, Vol. 135.

28. a) Flaherty S.M.O., Hold S.V., Cook M.J., Torres T., Hanack M., Blau W.J. Adv. Mater. 2003, 15, 19-32. b) de la Torre G., Vazquez P., Agullo-Lopez F., Torres T. Chem. Rev. 2004, 104, 3723-3750. c) Hanack M., Schneider T., Barthel M., Shirk J.S., Flom S.R., Pong R.G.S. Coord. Chem. Rev. 2001, 219, 235-258.

29. a) Hertel D., Müller C.D., Meerholz K. Chemie in Unserer Zeit 2005, 29, 336-347. b) D'Andrade B.W., Forrest S.R. Adv. Mater. 2004, 16, 1585-1595.

30. Dimitrakopoulos C.D., Malenfant P.R.L. Adv. Mater. 2002, 14 , 99-116. b) Sirringhaus H. Adv. Mater. 2009, 21, 3859-3873.

31. Martinez-Diaz M.V., de la Torre G., Torres T. Chem. Commun. 2010, 46, 7090-7108.

32. de la Torre G., Claessens C.G., Torres T. Chem. Commun. 2007, 2000-2015.

33. Bottari G., de la Torre G., Guldi D.M., Torres T. Chem. Rev. 2010, 110, 6768-6816. 